University of Nebraska - Lincoln

DigitalCommons@University of Nebraska - Lincoln

2012

\title{
A Synoptic Perspective of the Record 1-2 May 2010 Mid-South Heavy Precipitation Event
}

\author{
Joshua D. Durkee \\ Lee Campbell \\ Kyle Berry \\ Dustin Jordan \\ Gregory Goodrich
}

See next page for additional authors

Follow this and additional works at: https://digitalcommons.unl.edu/hprccpubs

Part of the Atmospheric Sciences Commons, Climate Commons, Environmental Indicators and Impact Assessment Commons, Environmental Monitoring Commons, Fresh Water Studies Commons, Hydrology Commons, Meteorology Commons, Natural Resources Management and Policy Commons, Sustainability Commons, and the Water Resource Management Commons

This Article is brought to you for free and open access by the High Plains Regional Climate Center at DigitalCommons@University of Nebraska - Lincoln. It has been accepted for inclusion in HPRCC Personnel Publications by an authorized administrator of DigitalCommons@University of Nebraska - Lincoln. 
Authors

Joshua D. Durkee, Lee Campbell, Kyle Berry, Dustin Jordan, Gregory Goodrich, Rezaul Mahmood, and Stuart Foster 


\title{
A Synoptic Perspective of the Record I-2 May 2010 Mid-South Heavy Precipitation Event
}

\author{
by Joshua D. Durkee, lee Campbell, Kyle Berry, Dustin Jordan, \\ Gregory Goodrich, Rezaul Mahmood, and Stuart Foster
}

D uring 1-2 May 2010, a series of strong thunderstorms led to 41,57, and 43 tornado, severe wind, and severe hail reports, respectively, across portions of the southern United States. In addition to severe weather, these storms also distributed recordsetting rainfall amounts across the mid-South region, which contributed to historic flooding across portions of central and western Kentucky and Tennessee (Fig. 1). This heavy precipitation event was sampled by multiple surface observational networks, including (but not limited to) 48 research-grade automated stations from the Kentucky Mesonet (www.kymesonet .org), first-order automated stations from the National Weather Service (NWS; www.ncdc.noaa.gov loa/ncdc.html), and Community Collaborative Rain, Hail and Snow Network Stations (CoCoRaHS), some of which recorded more than $350 \mathrm{~mm}$ of rain during the two-day period across portions of the region (Fig. 2).

The Kentucky Mesonet station in Bowling Green recorded the greatest rainfall intensity for the state, with $8.38 \mathrm{~mm}$ during a 5 -min period, and $50.8 \mathrm{~mm}$ during an hour (Fig. 3). Bowling Green, Kentucky, also received the greatest amount of rainfall in the state with $258 \mathrm{~mm}$, which broke the previous alltime two-day precipitation record for the state of $211 \mathrm{~mm}$ set during 6-7 December 1924. Moreover, Bowling Green received more than $120 \mathrm{~mm}$ each

AfFiliations: DurkeE, CAMpBell, BerRy, Jordan, Goodrich, MAHMOOD, AND Foster-Meteorology Program, Department of Geography and Geology, Western Kentucky University, Bowling Green, Kentucky

CORRESPONDING AUTHOR: Joshua D. Durkee, Department of Geography and Geology, Western Kentucky University, 1906 College Heights Blvd., Bowling Green, KY 42I0I

E-mail: joshua.durkee@wku.edu

DOI:10.1I75/BAMS-D-II-00076.I

(C)2012 American Meteorological Society day, which ranks as the sixth $(124.9 \mathrm{~mm})$ and eighth $(120.6 \mathrm{~mm})$ greatest daily rainfall totals in Kentucky since 1900. According to the NWS office in Nashville, Tennessee, Camden, Tennessee, received the most rainfall in the state with $493 \mathrm{~mm}$, which also set a new precipitation record. One CoCoRaHS station in Camden reported nearly $338 \mathrm{~mm}$ during a 24-h period, which was $7.62 \mathrm{~mm}$ shy of the all-time 24-h precipitation record for Tennessee. Nashville received more than $150 \mathrm{~mm}$ each day of the event, which ranked as the third-most $(158.2 \mathrm{~mm})$ and greatest $(184.2 \mathrm{~mm})$ 24-h rainfall accumulations of all time, and subsequently marked the wettest May on record for the city. In fact, many prior rainfall records that fell to the 1-2 May 2010 extratropical heavy precipitation event were originally produced by systems that were tropical in origin (e.g., Hurricanes Frederic and Katrina in 1979 and 2005, respectively).

Dating back to November 2009, antecedent precipitation across central Kentucky and Tennessee was as much as $300 \mathrm{~mm}$ below normal, which resulted in moderate drought conditions, according to the U.S. Drought Monitor. However, despite the relatively dry surface conditions, the intense rainfall that began 1 May resulted in runoff into nearby streams and rivers. Repeated heavy precipitation during the 48 -h period ultimately helped produce 20 new flood-stage records within six river basins across the region. The Cumberland River in Nashville breached the major flood stage by $2 \mathrm{~m}$, with a record crest of 15.6 $\mathrm{m}$, which contributed to the historic flooding of the downtown area of Nashville.

The Hydrometeorological Design Studies Center is a branch of NOAA's NWS that is currently in charge of providing precipitation frequency estimates for the United States (HDSC; www.nws. noaa.gov/oh/hdsc/index.html). According to the HDSC, the estimated precipitation frequency outcome for a large portion of western Tennessee was 


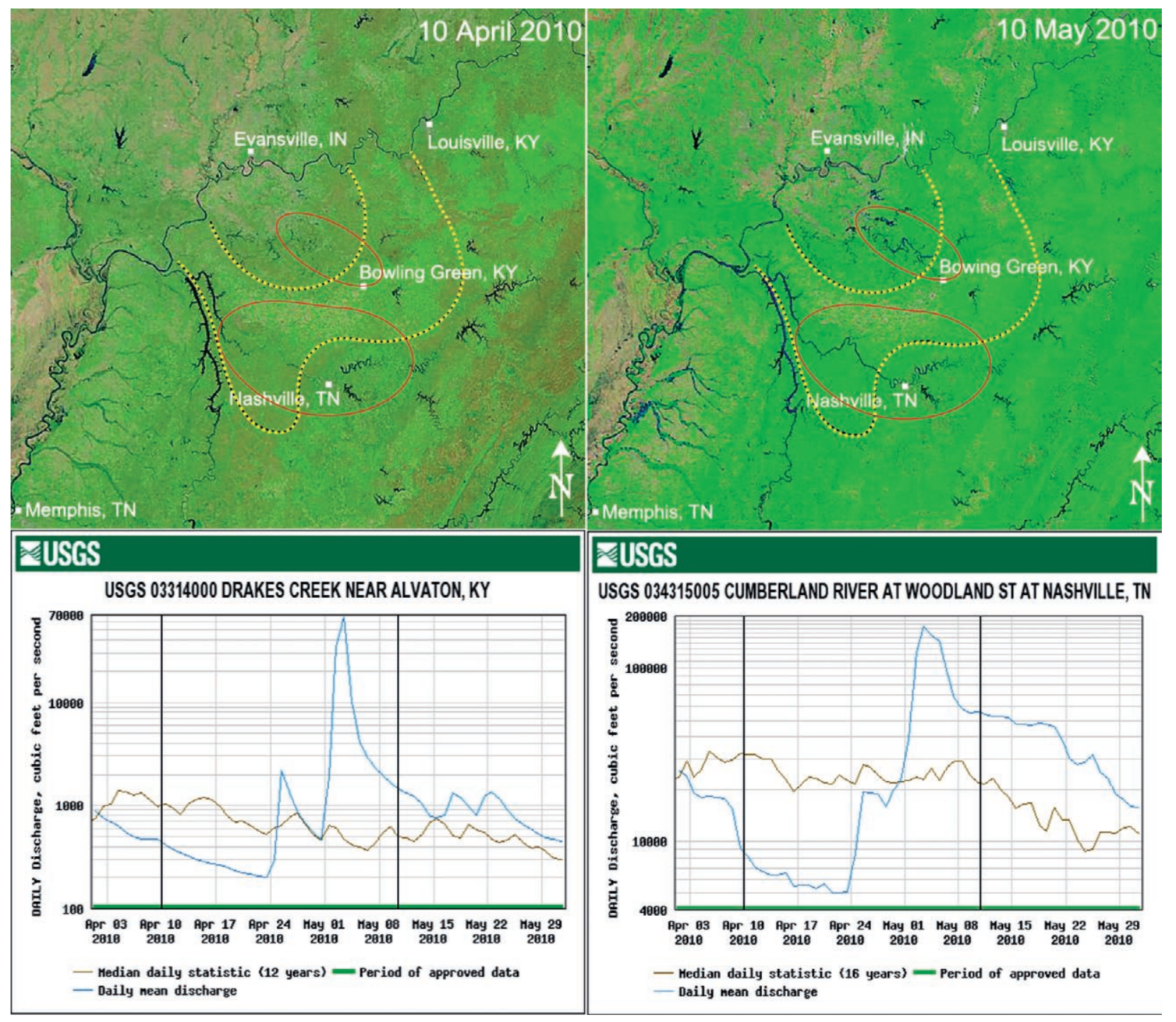

FIG. I. (Top) Modis Terra 1000-m false color RGB image, highlighting changes in the waterways between $10 \mathrm{Apr}$ and 10 May 2010 as a result of the I-2 May 2010 record precipitation and flood event across the midSouth. Red circles highlight changes in the visibility of the waterways before and after the event. Dotted lines demarcate local karst boundaries. (Bottom) Daily stream discharge for (left) Drakes Creek near Alvaton and Bowling Green, Kentucky, and (right) the Cumberland River in Nashville, Tennessee. Bold vertical black lines mark the dates of the satellite imagery.

a 1,000-year event. Recurrence intervals across south-central Kentucky counties were as high as 200 years. Unfortunately, the intense rainfall and resultant widespread flood led to 26 fatalities (4 in Kentucky and 22 in Tennessee), more than $\$ 2$ billion dollars in private-property damage, and more than 11,000 ill-affected structures across the region (Fig. 4). Urbanized and densely populated areas, including nearby or within Nashville and Memphis, Tennessee, were among the hardest hit in terms of flood-related damages and fatalities.
Given the widespread disastrous outcomes left behind from this particularly rare, heavy precipitation event for this region, it is imperative that we identify the synergy of the leading atmospheric and land-surface processes that contributed to the rainfall component of this event. The purpose of this discussion is to provide a brief analysis of the key synoptic-scale features and other atmospheric and land-surface constituents that played important roles in the development, magnitude, and mesoscale distribution of this historic rainfall event. 
SYNOPTIC ANALYSIS. The upper-air data used in this analysis included North American Regional Reanalysis (32 km x $32 \mathrm{~km}$ ) (NARR) 250- and 500-hPa heights and winds, and 850-hPa heights, winds, and temperatures, and were analyzed using the Integrated Data Viewer provided by Unidata (IDV; www .unidata.ucar.edu/software/idv). The National Centers for Environmental Prediction/National Center for Atmospheric Research (NCEP/NCAR) Reanalysis Data were used to analyze $2.5^{\circ} \times 2.5^{\circ}$ gridded $925-\mathrm{hPa}$ winds, 500-hPa heights, and precipitable water (PW) data using geographic information systems (GIS). Standardized anomalies of daily composite 500$\mathrm{hPa}$ heights and PW fields were calculated from the NCEP/NCAR data using 21-day centered means from a 30-yr base period of 1980-2009, given by

$$
\sigma_{\mathrm{A}}=\frac{X-\mu}{\sigma},
$$

where $X$ is the observed grid-point value, $\mu$ is the centered 21-day climatological mean, and $\sigma$ is the standard deviation. Derived total precipitable water (TPW) was analyzed from Special Sensor Microwave Imager/Advanced Microwave Scanning Radiometer for EOS (SSMI/AMSRE) via the Morphed Integrated Microwave Imagery (MIMIC-TPW) product, produced by the Cooperative Institute of Meteorological Satellite Studies at the University of Wisconsin-Madison. Precipitation data were analyzed from Kentucky Mesonet, NWS first-order, and CoCoRaHS observations, and level 2 radar reflectivity (KOHX; Nashville).

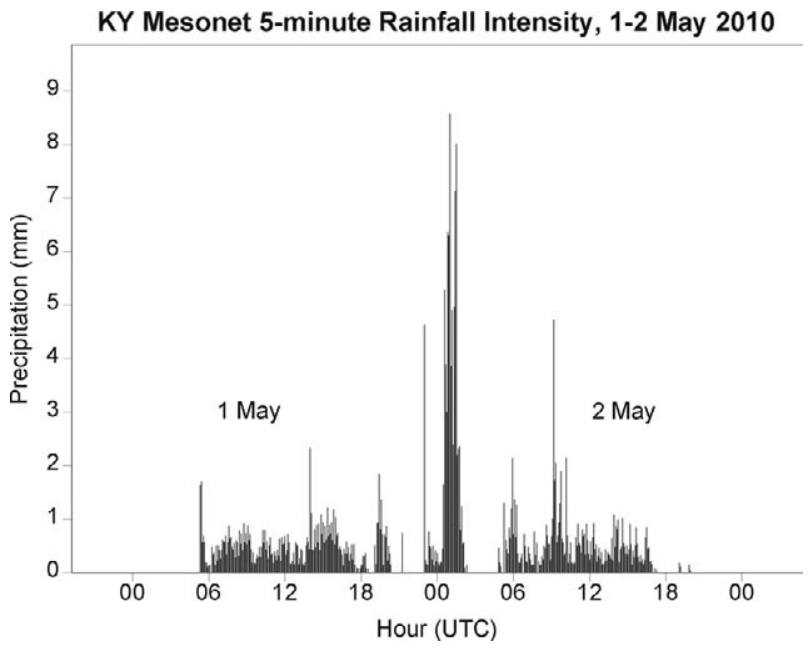

FIG. 3. Kentucky Mesonet 5-min rainfall rates over Bowling Green, Kentucky, during I-2 May 2010.

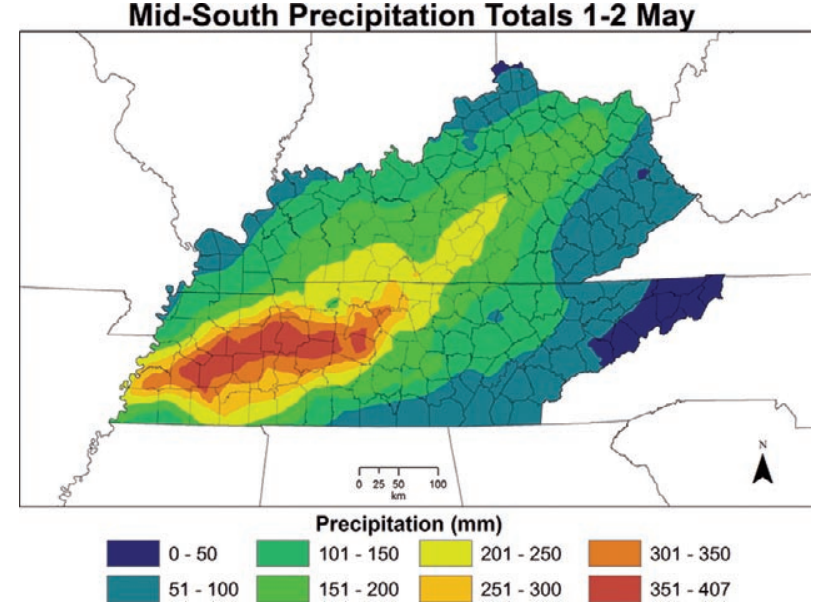

FIG. 2. Multisource precipitation map showing rainfall accumulations across Kentucky and Tennessee, observed from the Kentucky Mesonet, NWS first-order stations, and CoCoRaHS networks.

Leading up to the event, the synoptic circulation (not shown) during 29-30 April 2010 was characterized by a broad, developing trough and subtropical ridge pattern over the western and eastern United States, respectively. This upper-air circulation initially forced a steady lowlevel south-southwesterly surge of considerably warm, moist air across the Tennessee-Kentucky region. According to the NOAA Hybrid Single-Particle Lagrangian Integrated Trajectory (HYSPLIT) Model, backward air-parcel trajectories starting from Bowling Green and Camden at 1,296 and 1,280 m AMSL ( 845 hPa), respectively, originated from the Intertropical Convergence Zone (ITCZ) on the Pacific Ocean side of Central

\section{Property Damage and Fatalities by County}

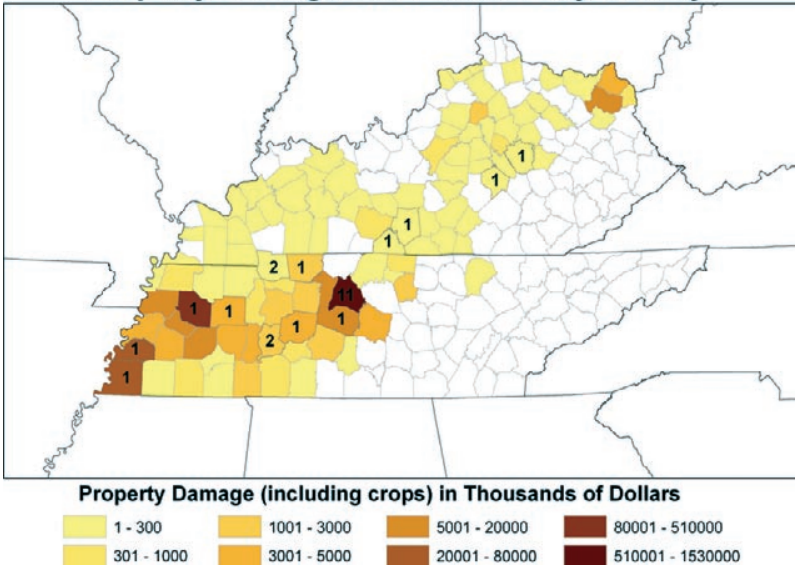

Fig. 4. Casualties, and property and crop damages by county during I-2 May 2010. 


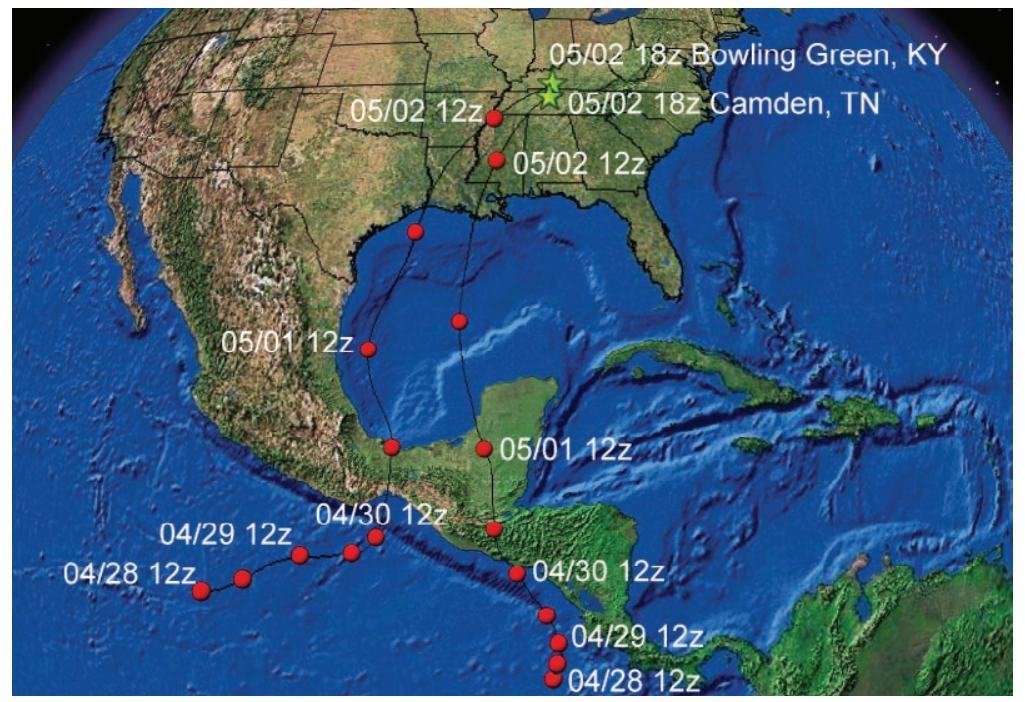

FIG. 5. NOAA HYSPLIT backward air-parcel trajectories starting from Bowling Green, Kentucky, and Camden, Tennessee, at I,296 and I,280 $\mathrm{m}$ AMSL ( $845 \mathrm{hPa})$, respectively, from 2 May 2010 at I 800 UTC to 29 Apr 2010 at I200 UTC.

America as early as 29 April 1200 UTC (Fig. 5). As the south-southwest/north-northeast oriented low-level, tropical Pacific originating moisture axis set up just east of the Mississippi River, surface dew points across the region increased from $\sim 7^{\circ}$ to $20^{\circ} \mathrm{C}$ during this period. Surface temperatures of around $25^{\circ} \mathrm{C}$ were observed as far north as south-central Wisconsin and Lower Michigan, in association with the surface low-pressure circulation over the northern Great Plains and its attendant warm frontal boundary.

Farther downstream, a closed upper-level low was positioned over the Gulf of St. Lawrence in eastern Canada, and the atmospheric pattern was suggestive of a negative phase of the North Atlantic Oscillation (NAO), as indicated by relatively strong ridging across the northern Atlantic. The negative NAO inhibited the eastward progression of the upstream synoptic pattern and played an important role in amplifying the meridional component of the trough and ridge across the United States. Together, the concatenation of these synoptic processes sufficiently preconditioned the atmospheric environment over the mid-South region for the record precipitation and catastrophic flood event.
By 1 May 2010, the meridional upper-level circulation across North America and the northern Atlantic had intensified into an anomalously high-amplitude synoptic wave pattern. Daily composite standardized height anomalies ranged from -6 to +6 across the midlevel trough and ridge, respectively (Fig. 6). Figure 7 shows daily composite circulation features at 250, 500, and $850 \mathrm{hPa}$ for 1 May (left column) and 2 May (right column). During 1 May, the 250-hPa circulation exhibited a jet-stream wind maximum downstream of the positively tilted trough axis that extended from the northern Great Plains through the Four Corners region, and diffluent southwesterly and westerly flow over the mid-South. In response to the deepening trough and increasing jet-stream winds, a corridor of southwesterly 850 $\mathrm{hPa}$ winds advecting deep tropical moisture-referred to as an atmospheric river (for a thorough discussion on the nature of the atmospheric river during the 12 May 2010 event, see Moore et al. 2011) —strengthened along and east of the Mississippi River Valley (see also Fig. 5). At the surface and just upstream of the warm sector, a weak low-pressure center developed in Arkansas, along a southwest/northeast oriented surface stationary boundary. Downstream across portions of western and central Tennessee and Kentucky, and into

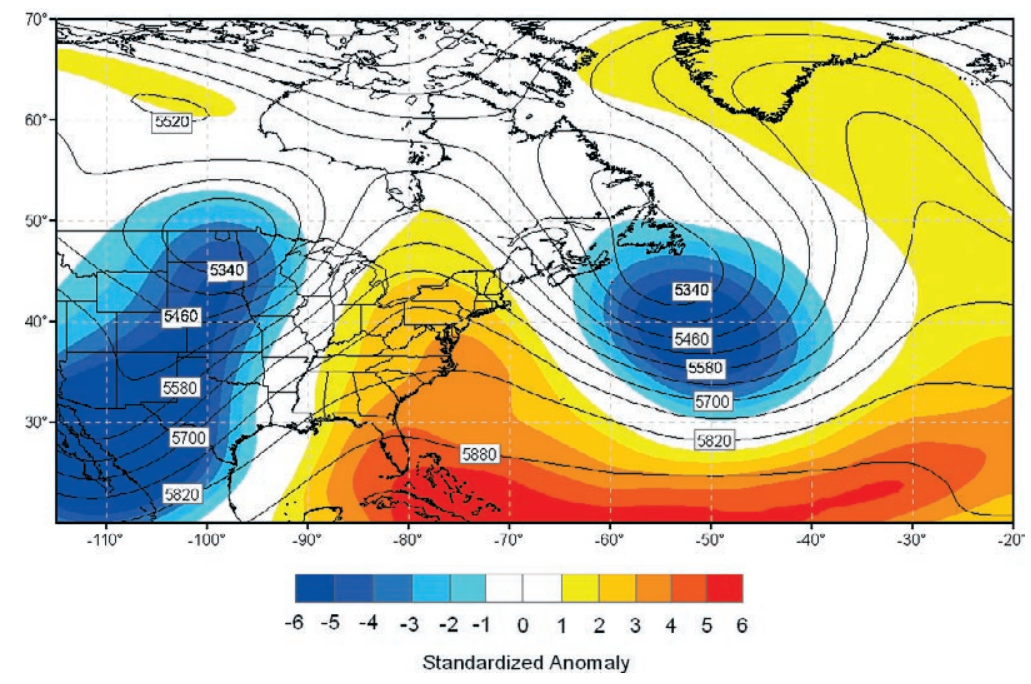

FIG. 6. NCEP/NCAR Reanalysis data showing daily composite 500-hPa heights $(\mathrm{m})$ and standardized anomalies for I May 2010. 
central Indiana, a PW axis with the same orientation as the surface boundary contained values of $37-40 \mathrm{~mm}$, which were +2 standard deviations above normal for this time (Fig. 8a). Dew points across western and central Tennessee and Kentucky were around $25^{\circ}$ and $21^{\circ} \mathrm{C}$, respectively. Together, these synoptic-scale
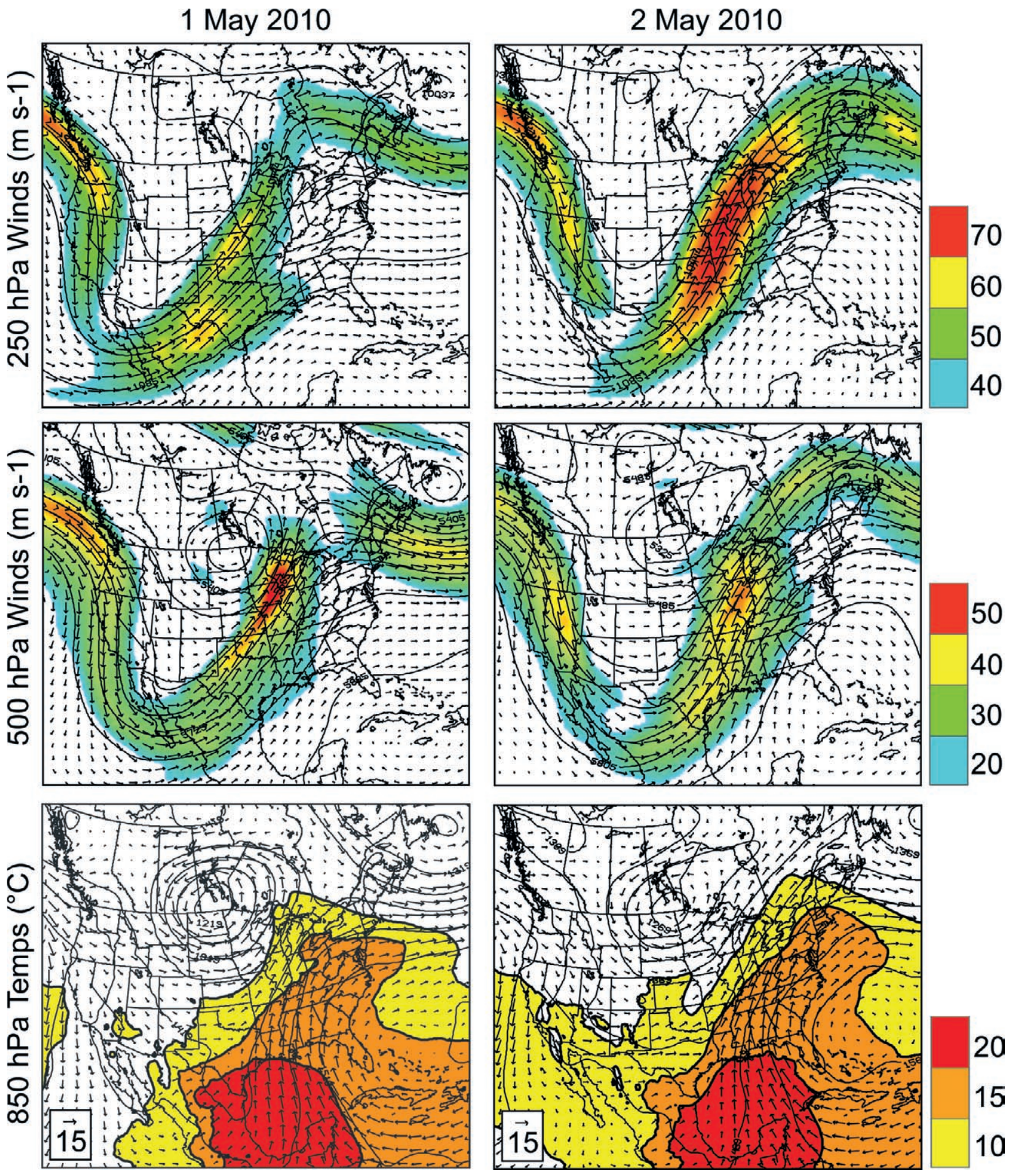

Fig. 7. North American Regional Reanalysis (NARR) data showing daily composite 250 - and 500 -hPa heights $(\mathrm{m})$ and winds $\left(\mathrm{m} \mathrm{s}^{-1}\right)$, and $850-\mathrm{hPa}$ heights $(\mathrm{m})$, winds $\left(\mathrm{m} \mathrm{s}^{-1}\right)$, and temperatures (starting at $10^{\circ} \mathrm{C} ; 5^{\circ}$ intervals) for (left column) I May and (right column) 2 May 2010. 

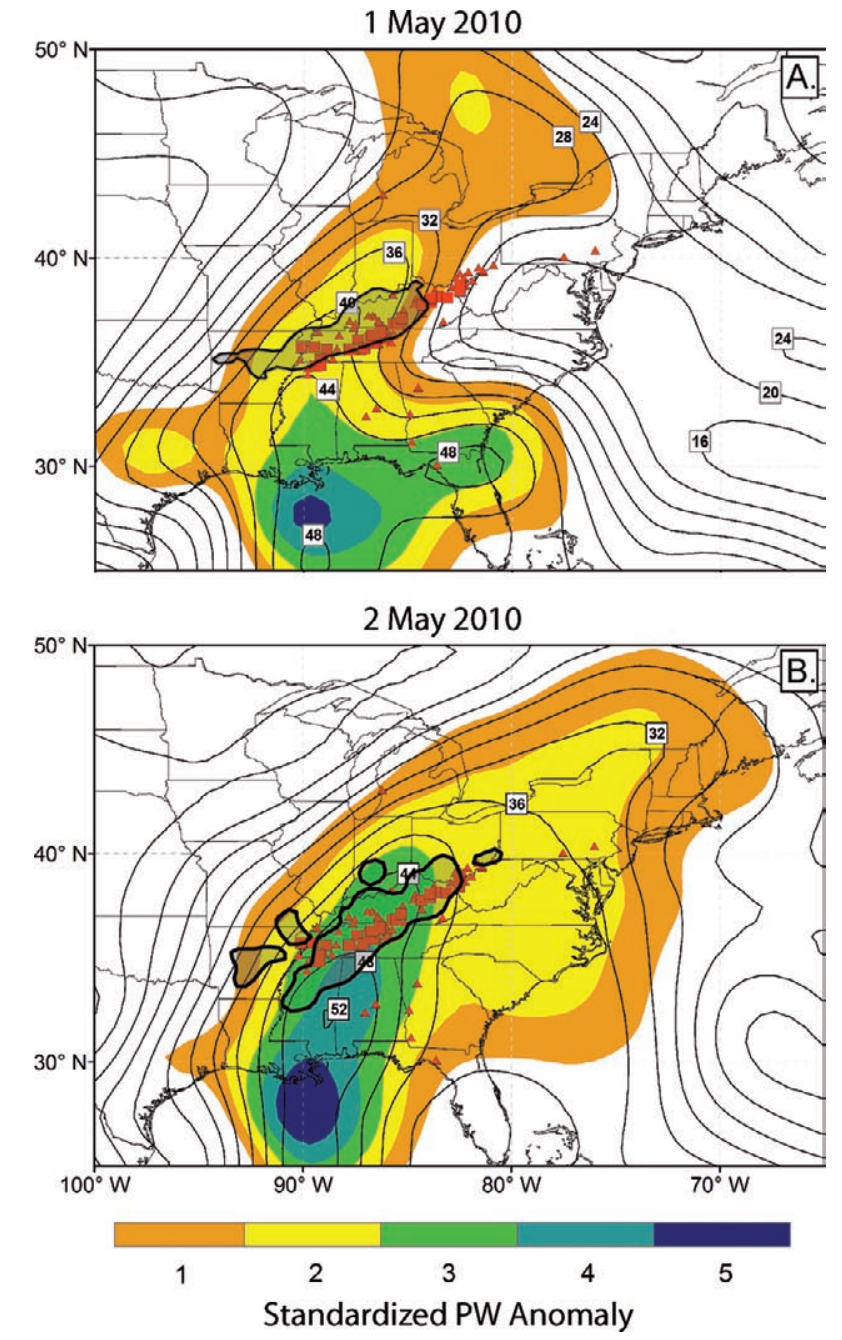

FIG. 8. NCEP/NCAR Reanalysis data showing daily composite precipitable water $(\mathrm{mm})$ (thin contours) and standardized anomalies (shaded) for (a) I May and (b) 2 May 2010. Bold outlined areas demarcate areas with upward vertical motion with the outer extent starting with omega values of $-0.3 \mathrm{~Pa} \mathrm{~s}^{-1}$. Triangles indicate the locations of precipitation accumulation records for the month of May. Squares show the locations of all-time 24-h precipitation accumulation records.

processes, particularly the continuous flux of deep tropical moisture across the mid-South, in part, aided in sufficient forcing supportive for large-scale vertical ascent and heavy rainfall across the region.

By 2 May 2010, the amplitude of the upper-air circulation intensified with relatively little eastward progression (see Fig. 7, right column). Downstream of the 250-hPa trough that continued to deepen across the intermountain west, the core of the jet strengthened along the poleward component of the amplified and

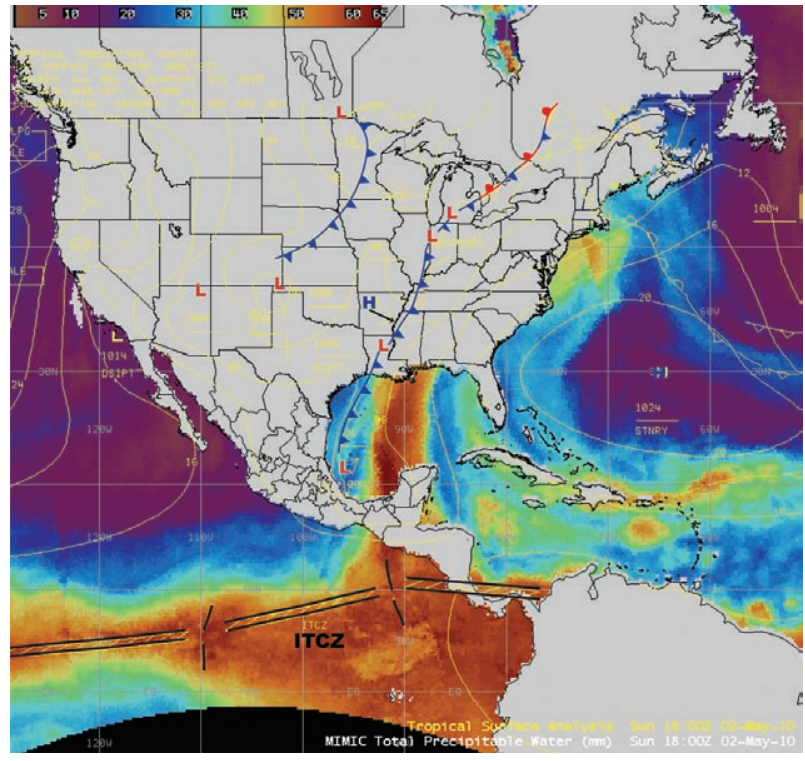

Fig. 9. Tropical surface analysis, and MIMIC-total precipitable water $(\mathrm{mm})$ product (over oceans only).

anomalous ridge across the east and southeast United States. While the midlevel winds began to increase over the mid-South, the surface frontal boundary slowly began its initial advancement across the Mississippi River. During this time, the low-level winds strengthened and continued to advect deep tropical moisture across the region. The tropical surface analysis and MIMIC-TPW product shown in Fig. 9 highlights the rich plume of atmospheric moisture with a confined axis that extended from the ITCZ, out in advance of the slow-moving surface front. At this time, $\mathrm{PW}$ values within the PW anomaly axis that extended through Nashville and Bowling Green increased appreciably by nearly $10 \mathrm{~mm}$-an amount +2 to +4 standard deviations above normal (see Fig. 8b). As the cold-frontal boundary slowly advanced, slow-moving regenerative thunderstorms continued to develop within the sufficiently moist, unstable warm sector across the mid-South.

Overall, from a synoptic-scale perspective, the key ingredients for preconditioning the atmosphere for any precipitation event include sufficient lift of relatively moist air, with enough instability to maintain the development and maintenance of the precipitating system. In the case of the 1-2 May 2010 record rainfall across the mid-South, an amplified upper-air circulation that initially developed on 29 April 2010 resulted in a particularly anomalous $500-\mathrm{hPa}$ trough and ridge across Mexico and the intermountain west and the Caribbean Sea, respectively. As a consequence of the placement and magnitude of these upper-air 
features, the Pacific ITCZ-originating atmospheric river advected historic amounts of PW poleward across the mid-South. Daily composite PW values near Nashville ranked below the 25 th percentile between 28 and 30 April before a sizeable increase to above the 75th and 99th percentiles on 1 and 2 May, respectively (Fig. 10a). In fact, Fig. 10b shows that PW values increased by up to +2 standard deviations above normal just between 1 and 2 May, when many of the aforementioned precipitation records were set. Meanwhile, downstream over the Atlantic Ocean, an anomalous closed upper-low circulation and negative NAO (Atlantic ridging) likely enhanced the amplification of the upstream synoptic wave pattern and helped to inhibit the eastward wave progression. Downstream of the quasistationary/ slow-moving surface front along the lower Mississippi River, numerous mesoscale convective systems (MCSs) developed across similar areas within the conditionally unstable and anomalously warm moist sector and repeatedly produced markedly intense rain rates.

While the heavy rainfall during the course of this event was largely derived from sufficient lift and instability within a particularly deep, anomalous moist layer that originated over the tropical Pacific ITCZ, the synergy of other important atmospheric and land-surface processes on different levels and scales also aided heavy MCS rainfall across the region. Maddox et al. (1979) and Doswell et al. (1996) (among other studies) highlight the importance of system propagation and cell motion speed, as well as the orientation of the surface frontal boundary and the upper-level winds with respect to heavy rainfall and flood potential. Both studies show that flood potential increases dramatically when cell motion is parallel to both the upper-level circulation and a slow-moving frontal boundary.

During 1-2 May, rainfall totals were exacerbated by storm motions that were closely parallel to both the upper-air circulation and surface quasistationary/slow-moving cold-frontal boundary. Corfidi (2003) describes the role of gust-front orientation with respect to concurrent upwind and downwind system propagation within environments of largely unidirectional mean winds. With the 1-2 May 2010 event, the large-scale circulation was conducive for forward-propagating linear storm structures that produced upwind outflow boundaries that led to steady back-building and repeated cell development across the same areas. According to the 1 May 1130 UTC KOHX Nashville NWS severe weather bulletin (nearly $5 \mathrm{~h}$ into the event), estimated cell motion was out of the southwest at $17.5 \mathrm{~m} \mathrm{~s}^{-1}$. The storm vectors

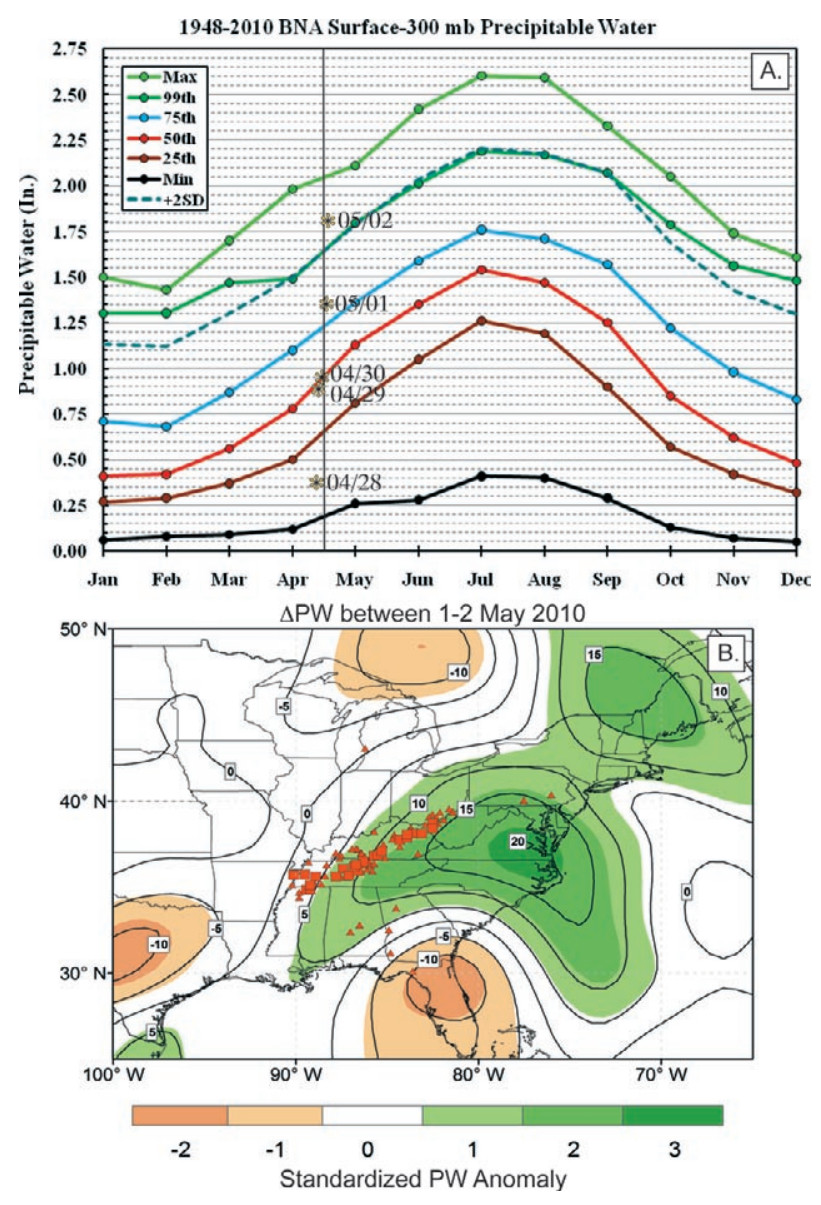

FIG. 10. (a) Annual PW (in.) climatology for Nashville, Tennessee ( $w w w . c r h . n o a a . g o v / u n r / ? n=p w)$. Yellow asterisks indicate daily composite NCEP/NCAR Reanalysis PW values for the grid point closest to Nashville, Tennessee, for 28 Apr-2 May 2010. (b) As in Fig. 8b except for the change in PW $(\mathrm{mm})$ and standardized PW anomalies between I and 2 May 2010.

were oriented nearly parallel to the quasistationary surface boundary, with estimated mean $0-6-\mathrm{km}$ winds out of the south-southwest at $19.5 \mathrm{~m} \mathrm{~s}^{-1}$. Meanwhile, animated radar reflectivity indicated that MCS propagation was toward the east-southeast at roughly half the storm motion and mean $0-6 \mathrm{~km}$ wind magnitudes (Fig. 11a-d). By 2 May 1153 UTC, the KOHX Nashville NWS severe-weather bulletin estimated that cell motion was more oriented with the surface front out of the southwest at $20.1 \mathrm{~m} \mathrm{~s}^{-1}$. As a result, many locations were inundated by heavy rains from regenerative storms (Fig. 11e-h).

In addition to synoptic and mesoscale atmospheric forcing, we suggest that mesoscale land-surface/ atmosphere interactions may have also played an 


\section{May 2010}
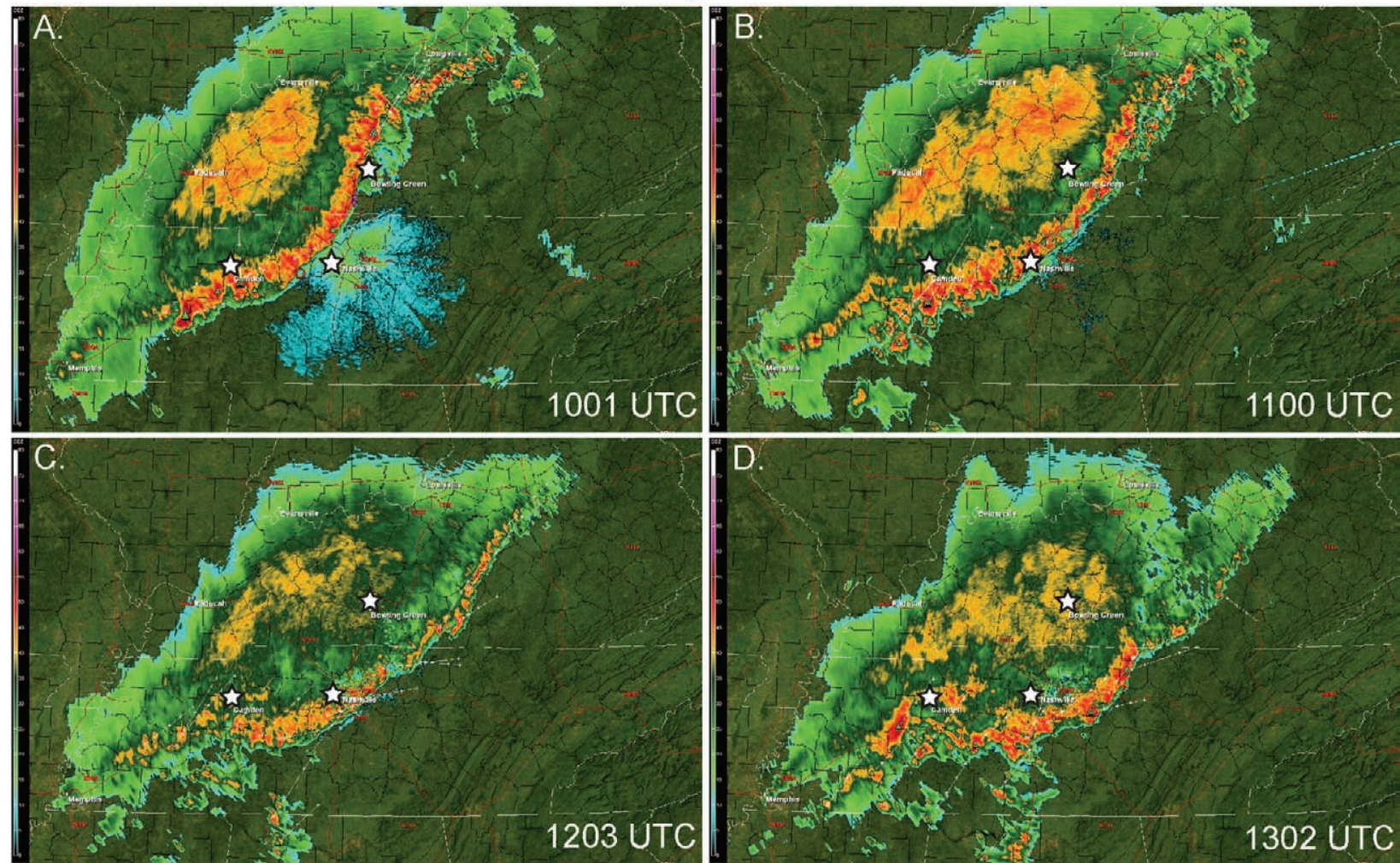

2 May 2010
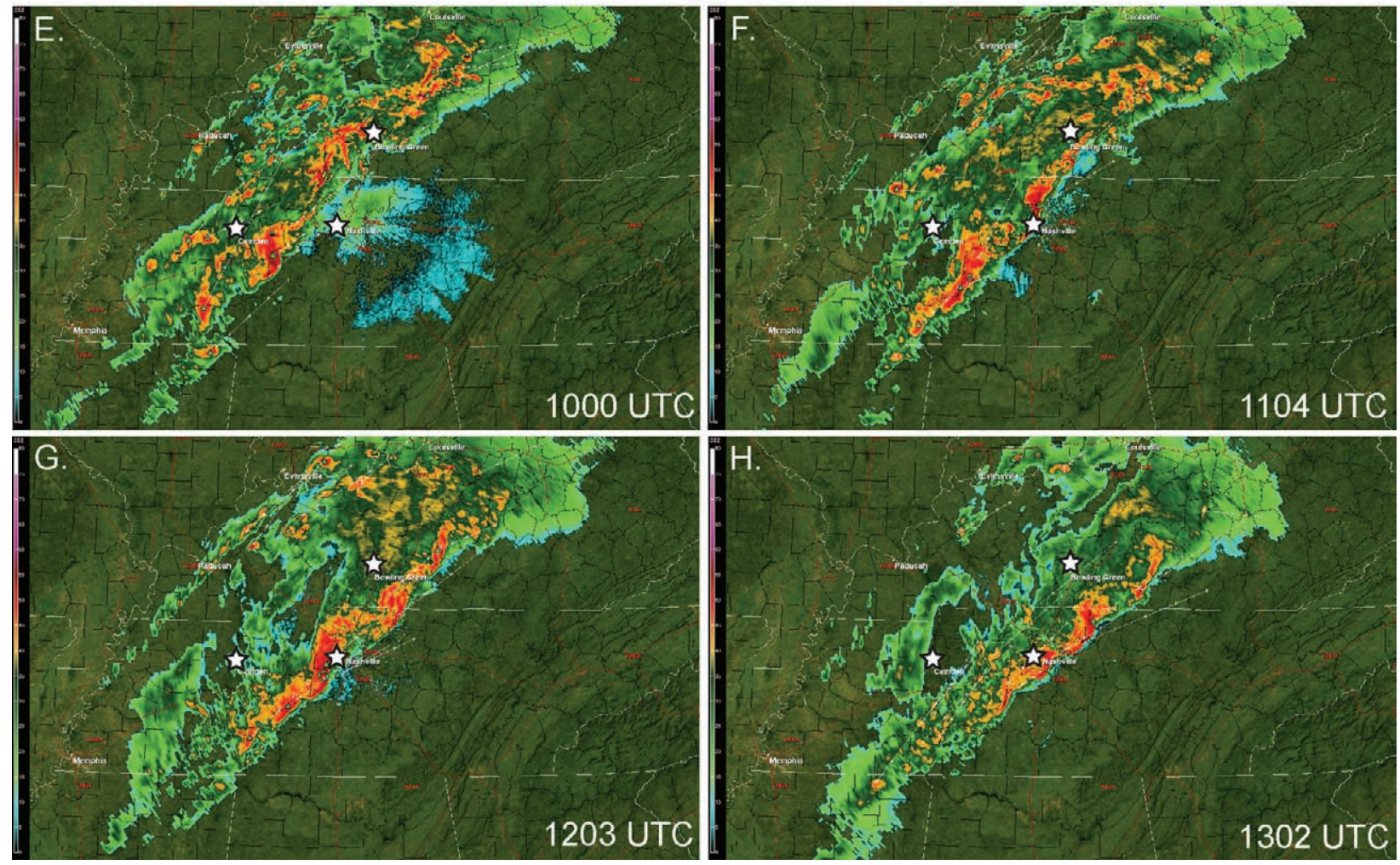
FIG. II (opposing page). KOHX Nashville NWS level 2 radar reflectivity shown using Gibson Ridge Software (www.grlevelx.com) for (a)-(d) I May 2010 during 100I, I100, 1203, and 1302 UTC, respectively, and (e)-(f) 2 May 2010 during 1000, I104, 1203, and 1302 UTC, respectively. From west to east (left to right), white stars mark the locations of Camden, Tennessee; Nashville, Tennessee; and Bowling Green, Kentucky, respectively.

important role in the spatial distribution of the rainfall over the region. Specifically, some locations that received the heaviest localized precipitation (e.g., Camden, Nashville, and Bowling Green) are located along or adjacent to well-developed karst hydrogeologic boundaries (see Figs. 1 and 11). The karst landscape, due to its geomorphologic characteristics, allows relatively rapid draining of surface water and with time, subsequent development of relatively dry or even drought conditions. Thus, the hydrogeologic settings of a well-developed karst environment can also alter local soil-moisture distributions, which can manifest in important land-surface/atmosphere interactions. This is not surprising, because it is also well known that heterogeneity in soil-moisture distribution and wet-dry transitions can promote localized mesoscale circulations and subsequent convection.

In a sensitivity analysis for precipitation over karst landscapes in Kentucky, Leeper et al. (2011) have shown that even under moderate-to-strong synoptic circulations, adjacent wet/dry land-surface conditions can modify the energy balance, the evolution of the planetary boundary layer, mesoscale circulations, and subsequent location of convection. Therefore, it is plausible to consider that relatively dry antecedent conditions (dating back to November of the previous year) near karst land-surface boundaries across west-central Kentucky and Tennessee provided this type of relative wet-dry transition and potentially offered a favorable localized environment for enhanced convection and precipitation during the course of this event. Given the scope of this study, the extent to which enhanced convection and precipitation during the 1-2 May 2010 historic precipitation event was influenced by local karst hydrogeologic land-surface/atmosphere interactions will be the focus of future work.

In summary, it is not uncommon to see a coincident broad large-scale trough and ridge configuration across the western and eastern United States during the spring transition season, respectively. While this type of synoptic circulation set the initial foundation for the historic 1-2 May 2010 mid-South heavy precipitation event by preconditioning the region via destabilization and anomalous moisten- ing of the atmosphere, the synoptic pattern itself was not uncommon with respect to heavy rain and flash-flood potential. The results presented here are consistent with other studies that examined atmospheric aspects of heavy precipitation events [e.g., Grumm and Hart (2001b) and Hart and Grumm (2001b)]. According to the classic study by Maddox et al. (1979) that examined large-scale atmospheric aspects of flash floods, the synoptic and mesoscale setup from which the historic mid-South flood of 2010 was spawned is relatively common [Fig. 12; cf., Maddox et al. (1979), Fig. 6]. What makes the 2010 event unique is that the magnitude and quasistationary nature of the synoptic pattern was such that a continuous fetch of water vapor from the tropical Pacific ITCZ supplied numerous, long-lasting MCSs with training cells, which resulted in widespread record rainfall totals (see Fig. 8). Lastly, interactions between the local karst land-surface across the region and the atmosphere may have also played a role in determining the location of some of the heavy rainfall.

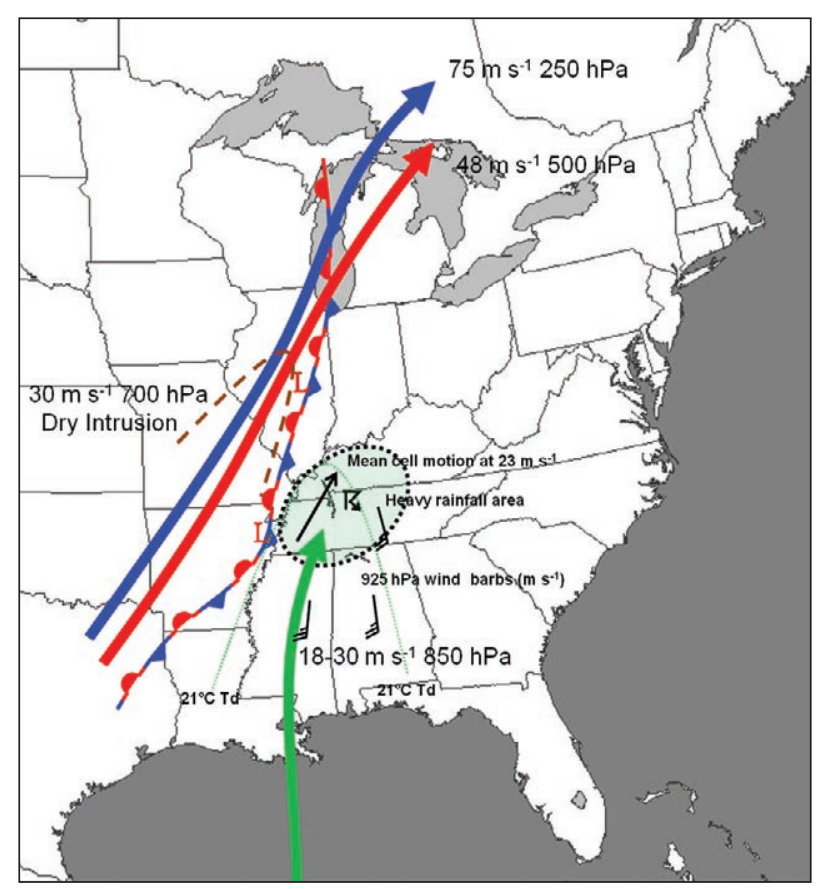

FIG. 12. Schematic composite of the synoptic features during I-2 May 2010. 
ACKNOWLEDGMENTS. We would like to acknowledge Tom Salem, Jeff Waldstreicher, and two anonymous reviewers for their insightful comments, which helped improve the manuscript. We would also like to thank Anthony Wimmers, Christopher Velden, Scott Bachmeier, and the Cooperative Institute of Meteorological Satellite Studies at the University of Wisconsin-Madison for their assistance with the satellite data used in this study.

\section{FOR FURTHER READING}

Burt, C. C., and M. Stroud, 2004: Extreme Weather. W.W. Norton and Co., 304 pp.

Chen F., and R. Avissar, 1994: Impact of land-surface moisture variability on local shallow convective cumulus and precipitation in large-scale models. J. Appl. Meteor., 33, 1382-1401.

Cifelli, R., N. Doesken, P. Kennedy, L. D. Carey, S. A. Rutledge, C. Gimmestad, and T. Depue, 2005: The Community Collaborative Rain, Hail, and Snow Network: Informal education for scientists and citizens. Bull. Amer. Meteor. Soc., 86, 1069-1077, doi:10.1175 /BAMS-86-8-1069

Corfidi, S. F., 2003: Cold pools and MCS propagation: Forecasting the motion of downwind-developing MCSs. Wea. Forecasting, 18, 997-1017.

Doswell III, C. A., H. E. Brooks, and R. A. Maddox, 1996: Flash flood forecasting: An ingredients-based methodology. Wea. Forecasting, 11, 560-581.

Draxler, R. R., and G. D. Rolph, 2011: HYSPLIT (Hybrid Single-Particle Lagrangian Integrated Trajectory) Model access via NOAA ARL READY website. NOAA Air Resources Laboratory. [Available online at http:// ready.arl.noaa.gov/HYSPLIT.php.]

Groves, C., C. Bolster, and J. Meiman, 2005: Spatial and temporal variations in epikarst storage and flow in south central Kentucky's Pennyroyal Plateau Sinkhole Plain. U.S. Geological Survey Scientific Investigations Report 2005, 64-73.

Grumm, R. H., and R. E. Hart, 2001a: Standardized anomalies applied to significant cold season weather events: Preliminary findings. Wea. Forecasting, 16, 736-754.

— , and — 2001b: Anticipating heavy rainfall: Forecast aspects. Preprints, Symp. Precipitation Extremes: Prediction, Impacts, and Responses, Albuquerque, NM, Amer. Meteor. Soc., 66-70.

Hart, R. E., and R. H. Grumm, 2001a: Using normalized climatological anomalies to rank synoptic-scale events objectively. Mon. Wea. Rev., 129, 2426-2442.

— and — 2001b: Anticipating heavy rainfall events: Forecast aspects. Preprints, Symp. Precipitation Ex- tremes: Prediction, Impacts, and Responses, Albuquerque, NM, Amer. Meteor. Soc. 271-275.

Hydrometeorological Design Studies Center, cited 2010: Precipitation frequency data server. [Available online at www.nws.noaa.gov/oh/hdsc/index.html.]

Kalnay, E., and Coauthors, 1996: The NCEP-NCAR $40-$ year Reanalysis Project. Bull. Amer. Meteor. Soc., 77, 437-471.

Kentucky Mesonet, cited 2010: Monthly climatological summary. [Available online at www.kymesonet.org /historical_data.php.]

Kusselson, S., L. Zhao, R. Kuligowski, S. Kidder, J. Forsythe, and A. Jones, 2010: The Tennessee flood of May 2010: A satellite perspective. 35th Conf. of the National Weather Association, Tucson, AZ.

Leeper, R., R. Mahmood, and A. I. Quintanar, 2011: Influence of karst landscape on planetary boundary layer atmosphere: A weather research and forecasting (WRF) model-based comparison. J. Hydrometeor., 12, 1512-1529.

Maddox, R. A., C. F. Chappell, and L. R. Hoxit, 1979: Synoptic and meso-alpha scale aspects of flash flood episodes. Bull. Amer. Meteor. Soc., 60, 115-123.

Mesinger, F., and Coauthors, 2006: North American regional reanalysis. Bull. Amer. Meteor. Soc. 87, 343-360.

Moore, B. J., P. J. Neiman, F. M. Ralph, and F. E. Barthold, 2011: Physical processes associated with heavy flooding rainfall in Nashville, Tennessee, and vicinity during 1-2 May 2010: The role of an atmospheric river and mesoscale convective systems. Mon. Wea. Rev., 140, 358-378.

National Climatic Data Center, cited 2010: Storm events database. [Available online at www4.ncdc.noaa.gov /cgi-win/wwcgi.dll?wwevent $\sim$ storms.]

National Weather Service, cited 2010: Record floods of greater Nashville: Including flooding in Middle Tennessee and Western Kentucky, May 1-4, 2010. 93 pp. [Available online at www.nws.noaa.gov/os /assessments/pdfs/Tenn_Flooding.pdf.]

Rolph, G. D., 2011: Real-time Environmental Applications and Display System (READY) website. NOAA Air Resources Laboratory. [Available online at http:// ready.arl.noaa.gov.]

Taylor, C. M., D. J. Parker, and P. P. Harris, 2007: An observational case study of mesoscale atmospheric circulations induced by soil moisture. Geophys. Res. Lett., 34, L15801, doi:10.1029/2007GL030572.

Wimmers, A. J., and C. S. Velden, 2011: Seamless advective blending of total precipitable water retrievals from polar-orbiting satellites. J. Appl. Meteor. Climatol., 50, 1024-1036. 